\title{
Pengaruh penambahan media limbah jamur merang dalam pupuk organik cair terhadap konsentrasi kaslium
}

\author{
*Yuli Anggraini Putri, H. Hulyadi, Dahlia Rosma Indah \\ Program Studi Pendidikan Kimia, FSTT, Universitas Pendidikan Mandalika \\ ${ }^{*}$ Correspondence e-mail: uyenk.onot@gmail.com
}

\begin{abstract}
Abstrak: Pupuk organic cair merupakan pupuk yang berupa larutan dari hasil pembusukan bahan-bahan organik. Kombinasi whey tahu dan limbah jamur merang dengan penambahan starter mikroorganisme lokal (MOL) dapat diolah menjadi pupuk organik cair mengandung makro nutrient Kalium (K-total). Tujuan penelitian ini untuk mengetahui kandungan kalium optimum pada pupuk organik cair whey tahu dengan penambahan limbah jamur merang dan mikroorganisme lokal (MOL). Metode penelitian ini menggunakan penelitian eksperimen di laboratorium dengan menggunakan metode Rancangan Acak Lengkap (RAL) dengan dua: faktor 1 massa limbah jamur merang (Limbah jamur merang lama $600 \mathrm{gr}$ dan limbah jamur merang baru $600 \mathrm{gr}$ ) dan faktor 2 volume pupuk organik cair (masing-masing $1 \mathrm{~L}$ ). Hasil penelitian menunjukkan bahwa kandungan K-total tinggi terdapat pada perlakuan POC + LB yaitu $1,05 \%$.
\end{abstract}

Kata kunci: whey tahu, limbah jamur merang, MOL, kalium, pupuk organik cair

\section{The effect of the addition of mushroom waste media in liquid organic fertilizer to the concentration of cassava}

\begin{abstract}
Liquid organic fertilizer is a fertilizer in the form of a solution from the decay of organic matter. The combination of whey tofu and mushroom waste with the addition of local microorganism starter (MOL) can be processed into liquid organic fertilizer containing macro-nutrient potassium (K-total). The purpose of this study was to determine the optimum potassium content in the liquid organic fertilizer of whey tofu with the addition of mushroom waste and local microorganisms (MOL). This research method used experimental research in the laboratory using the Completely Randomized Design (CRD) method with two: a factor of 1 mass of mushroom waste (600 gr old mushroom waste and $600 \mathrm{gr}$ new mushroom waste) and a factor of 2 volume of liquid organic fertilizer (each -Each $1 L$ ). The results showed that the high total $K$ content found in the POC $+\angle B$ treatment was $1.05 \%$.
\end{abstract}

Keywords: whey tofu, edible mushroom waste, MOL, potassium, liquid organic fertilizer

How to Cite: Putri, Y., A., Hulyadi, H., \& Indah, D., R. (2020). Pengaruh penambahan media limbah jamur merang dalam pupuk organik cair terhadap konsentrasi kaslium. Empiricism Journal, 1(1), 28-38. doi:https://doi.org/10.36312/ej.v1i1.264

\section{PENDAHULUAN}

Pupuk merupakan bahan yang mengandung sejumlah nutrisi yang dibutuhkan oleh tanaman. Pemupukan adalah upaya pemberian nutrisi pada tanaman guna menunjang kelangsungan hidupnya. Pupuk dapat dibuat dari bahan organik dan anorganik. Sejak dulu sampai saat ini diketahui bahwa pupuk organik banyak dimanfaatkan sebagaian dalam sistem usaha tani oleh para petani (Sutedjo, 2010). Pupuk organik adalah pupuk yang diproses dari limbah organik seperti kotoran hewan, sampah, sisa tanaman, serbuk gergajian kayu, lumpur aktif, yang kualitasnya tergantung dari proses atau tindakan yang diberikan (Yulipriyanto, 2010). Pupuk organik merupakan bahan pembenah tanah yang paling baik dan alami dari pada bahan pembenah buatan/sintesis. Pada umumnya pupuk organik mengandung hara makro N, P, K rendah tetapi mengandung hara mikro dalam jumlah cukup yang sangat diperlukan pertumbuhan tanaman. Sebagai bahan pembenah tanah, pupuk organik mencegah terjadinya erosi, pergerakan permukaan tanah (Crusting) dan retakan tanah, mempertahankan kelengasan tanah serta memperbaiki pengatusan dakhil (Internal drainase). 
Pemberian pupuk organik kedalam tanah dapat dilakukan seperti pupuk kimia (Sutanto, 2002).

Pupuk organik cair adalah jenis pupuk berbentuk cair, tidak padat, dan mudah sekali larut pada tanah dan membawa unsur-unsur penting untuk pertumbuhan tanaman. Pupuk organik cair mempunyai banyak kelebihan diantaranya, pupuk tersebut mengandung zat tertentu seperti mikroorganisme jarang terdapat dalam pupuk organik padat dalam bentuk kering (Syefani dan Lilia dalam Mufida, 2013). Menurut Hadisuwito (2007) pupuk organik cair merupakan larutan yang berasal dari hasil pembusukan bahan-bahan organik yang berasal dari sisa tanaman, kotoran hewan, dan manusia yang kandungan unsur haranya lebih dari satu unsur. Kelebihan dari pupuk organik cair adalah secara cepat mengatasi defisiensi hara, tidak bermasalah dalam pencucian hara, dan mampu menyediakan hara yang cepat.

Limbah industri tahu pada umumnya dibagi menjadi dua bentuk limbah, yaitu limbah padat dan limbah cair. Limbah padat pabrik pengolahan tahu berupa kotoran hasil pembersihan kedelai (batu, tanah, kulit kedelai, dan benda padat lain yang menempel pada kedelai) dan sisa saringan bubur kedelai yang disebut dengan ampas tahu. Limbah padat yang berupa kotoran berasal dari proses awal (pencucian) bahan baku kedelai dan umumnya limbah padat yang terjadi tidak begitu banyak (0,35 dari bahan baku kedelai), sedangkan limbah padat yang berupa ampas tahu terjadi proses penyaringan bubur kedelai. Ampas tahu yang terbentuk besarnya berkisar antara 25 - 35\% dari produk tahu yang dihasilkan (Kaswinarni, 2007).

Konsentrasi limbah tahu yang tepat dapat difungsikan sebagai pupuk cair untuk tanaman kangkung darat, dimana konsentrasi air limbah tahu $15 \%$ memberikan hasil yang paling optimal khususnya terhadap berat basah kangkung darat (Aliyenah, 2015). Pemberian air limbah tahu dapat dianggap sebagai pengganti pupuk cair organik, sehingga dapat memberikan hasil yang positif terhadap pertumbuhan tanaman lada hitam (Yap, 2012).

Pada pembuatan pupuk organik cair, perlu diperhatikan persyaratan atau standar kadarkadar bahan kimia serta $\mathrm{pH}$ yang terkandung di dalam pupuk organik tersebut. Berikut adalah persyaratan teknis minimal pupuk organik yang ditetapkan oleh Departemen Pertanian Republik Indonesia (Tabel 1).

Tabel 1. Standar kadar bahan kimia pada pupuk organic (Peraturan Menteri Pertanian No.28/Permentan/OT.140/2/2009)

\begin{tabular}{cc}
\hline Parameter & Standar \\
\hline Total N & $<2 \%$ \\
$\mathrm{C}$ organik & $>4 \%$ \\
Rasio C/N & $15-25 \%$ \\
$\mathrm{P}_{2} \mathrm{O}_{5}$ & $<2 \%$ \\
$\mathrm{~K}_{2} \mathrm{O}$ & $<2 \%$ \\
$\mathrm{pH}$ & $4-8$ \\
\hline
\end{tabular}

Unsur hara merupakan salah satu faktor yang menunjang pertumbuhan dan perkembangan tanaman. Hara nitrogen, fosfor, dan kalium merupakan faktor pembatas utama untuk produktivitas padi sawah. Respon padi terhadap nitrogen, fosfor, dan kalium dipengaruhi oleh beberapa faktor, diantaranya adalah penggunaan bahan organik. Bahan organik merupakan kunci utama dalam meningkatkan produktivitas tanah dan efisiensi pemupukan.Kalium merupakan unsur hara esensial tanaman, bahkan semua makhluk hidup. Tidak ada unsur lain yang dapat menggantikan fungsi spesifiknya di dalam tanaman, dan merupakan salah satu dari 3 unsur hara makro utama selain $\mathrm{N}$ dan $\mathrm{P}$. Fungsi penting $\mathrm{K}$ dalam pertumbuhan tanaman adalah pengaruhnnya pada efisiensi penggunaan air. Proses membuka dan menutup pori - pori daun tanaman, stomata, dikendalikan oleh konsentrasi $\mathrm{K}$ dalam sel yang terdapat di sekitar stomata (Winarso, 2005). Kalium didalam jaringan tanaman ada dalam bentuk kation dan bervariasi sekitar 1,7-2,7\% dari berat kering daun yang tumbuh secara normal. Ion $\mathrm{K}$ di dalam tanaman berfungsi sebagai aktivator dari banyak enzim yang berpartisipasi dalam beberapa proses metabolisme utama tanaman. 
Kalium (K) merupakan unsur hara yang dibutuhkan dalam jumlah banyak untuk mendukung pertumbuhan tanaman (Malezieux \& Bartholomew, 2003). Tetapi ketersediaannya dalam tanah umumnya rendah, sehingga kekurangan K selalu menjadi faktor pembatas untuk meningkatkan pertumbuhan dan produksi tanaman, karena sebagian besar $\mathrm{K}$ tanah berada dalam bentuk tidak tersedia. Banoelus et al (2002) mengungkapkan bahwa kalium memegang peranan penting dalam fungsi sel, termasuk pengaturan: (1) turgor, (2) keseimbangan muatan, dan (3) potensial membran serta aktivitas membran sitosol.

Kalium sangat vital dalam proses fotosintesis. Apabila $\mathrm{K}$ defisiensi maka proses fotosintesis akan turun, akan tetapi respirasi tanaman akan meningkat. Kejadiaan ini akan menyebabkan banyak karbohidrat yang ada dalam jaringan tanaman tersebut digunakan untuk mendapatkan energi untuk aktivitas - aktivitasnya sehingga pembentukan bagian bagian tanaman akan berkurang yang akhirnya pembentukan dan produksi tanaman berkurang (Vogel, 1985). Fungsi kalium menurut Kasmadi(2010), merupakan unsur esensial dalam sintesis protein, penting dalam pemecahan karbohidrat, proses pemberian energi bagi tanaman, membantu dalam keseimbangan ion dalam tanaman, membantu tanaman mengatasi gangguan penyakit, penting dalam pembentukan buah,dan meningkatkan daya tahan tanaman terhadap iklim yang tidak menguntungkan. Fungsi penting $\mathrm{K}$ dalam pertumbuhan tanaman ialah pengaruhnya pada efisiensi penggunaan air. Proses membuka dan menutup pori - pori daun tanaman (stomata). Kadar K tidak cukup (defisien) dapat menyebabkan stomata membuka hanya sebagian dan menjadi lebih lambat dalam penutupan. Gejala kekurangan K ditunjukkan dengan tanda - tanda terbakarnya daun yang dimulai dari ujung atau pinggir, bercak - bercak nekrotik berwarna coklat pada daun - daun dan batang yang tua (Mohsin, 2006). Seperti yang telah dijelaskan oleh BSNI (Badan Standar Nasional Indonesia) bahwa kandungan unsur NPK pada kompos organik memiliki standarisasi dengan jumlah minimal unsur NPK pada pupuk sebanyak $\mathrm{N} 0,40 \%, \mathrm{P} 0,10 \%$ dan K 0,20\% (Badan Standar Nasional Indonesia, 2004).

Jamur merang (volvariella volvacea L.) merupakan jamur yang paling banyak digunakan untuk aneka bahan pangan seperti campuran soup, pizza, pasta dan lain - lain. Rasa, tekstur, dan kandungan gizi yang tinggi menyebabkan jamur semakin banyak digunakan dan nilai ekonomi yang semakin menningkat. Jamur merang memerlukan persyaratan lingkungan yang khusus serta media tanam dan pemupukan (Sinaga, 2007), media tanam yang biasa digunakan adalah ampas kelapa sawit, ampas tebu, limbah kardus, limbah kapas dan sebagainya (Indra, 2008). Limbah yang digunakan harus terbebas dari kontaminasi agar yang tumbuh hanya jamur yang ditanam (Gunawan, 2000). Penggunaan ampas kelapa sawit sangat potensial karena produksinya dalam skala besar tersedia di daerah - daerah produksi kelapa sawit. Penggunaan limbah tersebut akan meningkatkan nilai ekonomi dari ampas sawit. Penggunaan jerami padi akan mengatasi masalah limbah hasil pertanian setelah panen padi di daerah - daerah produksi padi, sehingga dapat meningkatkan nilai ekonomi dari padi.

Jamur merang memiliki kandungan gizi yang lebih baik, dalam setiap 100 gram jamur merang menghasilkan kandungan nutrisi: protein 1,8\%, lemak 0,3\%, karboksilat $12-48 \%$ dari berat kering, kalsium $30 \mathrm{mg}$, zat besi $0,9 \mathrm{mg}$, tiamin (vitamin B) $0,03 \mathrm{mg}$, riboflavin 0,01 $\mathrm{mg}$, niacin 1,7 mg, vitamin C 1,7 gr, kalori $24 \mathrm{mg}$, serta kandungan air 93,3\%. Jamur merang juga bermanfaat untuk pengobatan seperti menurunkan kolesterol darah, dapat menanggulangi kekurangan gizi dinegara yang sedang berkembang seperti di Negara Asia dan Afrika, dan dapat digunakan sebagai obat-obatan. Jamur dapat mengubah selulosa menjadi polisakarida yang bebas kolesterol sehingga orang yang mengkonsumsinya terhindar dari resiko terkena serangan stroke.

Hasil kegiatan yang telah dilakukan adalah pembuatan media jamur dengan memanfaatkan limbah jerami padi.Jerami merupakan salah satu media alternatife yang dapat digunakan pada budidaya jamur merang.Jerami mengandung hara yang cukup lengkap baik hara makro maupun mikro. Secara umum hara N, P, K masing - masing sebesar $0,4 \% ; 0,2 \%$, 0,7\% serta $40 \%$ C (BPTP Kaltim, 2012). Kandungan nutrisi dalam 100 gram jerami padi terdiri dari selulosa sebanyak $29,63 \%$, dengan kandungan hemiselulosa sebanyak $17,11 \%$ dan lignin sebanyak 12,17\% (Hartini, 2012). Jerami padi biasanya dibakar atau dimnfaatkan sebagai pakan ternak. Jerami padi mempunyai serat yang tinggi tetapi proteinnya rendah. 
Jerami berfungsi sebagai substrat tempat menempelnya miselium dan sumber nutrisi, terutama karbon (Sukmadi et al. 2012).

Hampir semua bagian tanaman sagu mempunyai manfaat tersendiri, misalnya batangnya dapat dimanfaatkan sebagai tiang atau balok jembatan, daunnya sebagaiatap rumah, pelepahnya untuk dinding rumah, bahkan ampas sagu pun dapat diolah agar memiliki nilai jual.Dan ampas sagu cukup potensial untuk digunakan sebagai bahan utama dalam pembuatan kompos. Hal ini disebabkan karena ampas sagu merupakan limbah organik yang sangat reaktif terhadap senyawa bioaktivator, sehingga meningkatkan kandungan bahan organik ampas sagu (Islamiyati, 2009). Ampas sagu merupakan limbah dari empulur sagu yang telah diambil patinya. Kandungan pati sagu sebesar $18,5 \%$ dan sisanya $81,5 \%$ merupakan ampas sagu yang memiliki kandungan selulosa sebesar $20 \%$ dan lignin $21 \%$ (Kiat, 2006).

Semakin berkembanngnya usaha budidaya jamur, limbah yang dihasilkan akan semakin meningkat. Total limbah yang dihasilkan tergantung dari besar usaha dan jenis usaha. Limbah yang terdiri dari jerami, ampas sagu dan bahan lainnya merupakan limbahbudidaya jamur yang dihasilkan, sebagian besar merupakan limbah bagblog dari hasil panen. Limbah tersebut dikhawatirkan menjadi sarang hama dan penyakit yang sewaktu waktu menyerang jamur budidaya, tanaman pertanian, ternak dan manusia (Priyanto, 2013). Saat ini banyak petani jamur yang sudah mulai memanfaatkan limbah baglog tersebut menjadi sesuatu yang mempunyai nilai tambah bahkan dapat dijadikan sebagai usaha tambahan. Hal ini dilakukan dengan mencoba memanfaatkan limbah jamur tiram dan jamur merang untuk dijadikan kompos sebagai limbah padat organic agar memiliki nilai ekonomis tinggi.pemanfaatan limbah padat organik tersebut antara lain untuk meningkatkan produktivitas tanaman, sebagai pakan ikan dan bahan baku pupuk organik. Media jamur berupa limbah jerami padi, setelah pemanenan dapat dijadikan pupuk organik kompos.Pupuk kompos ini dapat diaplikasikan pada lahan pertanian untuk meningkatkan kesuburan tanah dan menghemat penggunaan pupuk kimia.Jerami mengandung hara yang cukup lengkap baik hara makro maupun mikro. Sebagai pupuk organik jerami padi tidak efektif dan efisien bila diandalkan sebagai sumber hara $\mathrm{N}$ dan $\mathrm{P}$, tetapi cukup efektif sebagai sumber $\mathrm{K}, \mathrm{Si}$, dan $\mathrm{C}$ (Badan Penelitian dan Pengembangan, 2007). Secara umum hara N, P, K masing - masing sebesar 0,4\%; 0,2\%; dan 0,7\% serta 40\% C (BPTP Kaltim,2012). Menurut hasil penelitian Aiip (2011) menunjukkan bahwa limbah budidaya jamur tiram berpengaruh nyata dalam meningkatkan serapan hara, pertumbuuhan, dan produksi tanaman kedelai dan padi gogo. Dosis limbah yang terbaik untuk produksi tanaman kedelai adalah $450 \mathrm{~g} / \mathrm{kg}$ tanah dan hasil produksi terbaik pada tanaman padi secara signifikan ditunjukkan oleh perlakuan limbah 300 $\mathrm{g} / \mathrm{kg}$ tanah.

Menurut Isroi (2009) mikroorganisme local adalah kumpulan mikroorganisme yang bisa "diternakkan", fungsinya dalam konsep zero waste adalah untuk starter yang berfungsi sebagai bioaktivator dalam pembuatan kompos organik. Mol menurut Purwasasmita (2009) dapat digunakan baik sebagai bioaktivator pupuk hayati dan sebagai pestisida organik terutama sebagai fungisida. Menurut Hersanti (2007) MOL mudah dibuat dan secara rinci MOL terdiri dari 3 komponen, yaitu: (a) karbohidrat yang dapat berasal dari air tajin, air cucian beras, nasi basi, singkong, kentang, gandum dan lain-lain,(b) glukosa dapat erasal dari gula merah yang diencerkan, gula pasir, gula batu, air gula atau air kelapa,(c) sumber bakteri berasal dari bahan - bahan makanan yang membusuk. Peran MOL dalam proses pengomposan selain sebagai nutrisi juga berperan sebagai komponen bioreaktor, juga sangat ekonomis karena hampir tanpa biaya. Hasil analisa Kurnia et al (2003) setiap MOL dengan bahan baku berbeda, akan mengandung jenis mikroba yang berbeda. MOL bisa dikembangbiakkan sendiri dari berbagai limbah atau sisa bahan pangan.

Pupuk organik cair adalah jenis pupuk berbentuk cair dan mudah sekali larut pada tanah dan membawa unsur - unsur penting untuk pertumbuhan tanaman. Pupuk organik cair mempunyai banyak kelebihan diantarnya, pupuk tersebut mengandung zat tertentu seperti mikroorganisme yang jarang terdapat dalam pupuk organik padat dalam bentuk kering (Mufida, 2013). 
Fermentasi merupakan proses yang dilakukan oleh mikroorganisme baik aerobmaupun anaerob yang mampu mengubah atau mentransformasikan senyawa kimia kompleks menjadi lebih sederhana. Hal tersebut bertujuan untuk mempercepat penyerapan nutrisi pada tanaman. Naswir (2008) mengatakan proses fermentasi dapat berlangsung dalam keadaan kedap udara (anaerob). Dalam proses fermentasi juga menghasilkan senyawa organik lain seperti asam laktat, asam nukleat, karbohidrat, protein, dan lain sebagainya. Senyawa senyawa organik ini juga dapat melindungi tanaman dari serangan penyakit.

Fermentasi merupakan suatu cara pengolahan melalui proses memanfaatkan penguraian senyawa dari bahan -bahan protein kompleks. Dalam pembuatan pupuk organik cair ini proses fermentasi dilakukan untuk mendegradasi $\mathrm{N}$ organik menjadi senyawa nitrat agar dapat diserap oleh tanaman.

Berdasarkan uraian tersebut limbah jamur merang hanya dapat digunakan untuk pembuatan pupuk organik padat atau kompos dan penulis perlu mencari variasi penambahan limbah jamur merang terhadap pupuk organic cair untuk menghasilkan pupuk organik cair yang memiliki kadar Kalium (K-Total) optimum. Penelitian ini bertujuan untuk mengetahui pengaruh massa limbah jamur merang dan volume pupuk organik cair terhadap konsentrasi kalium.

\section{METODE}

Jenis penelitan ini adalah eksperimen di Laboratorium. Penelitian eksperimen adalah metode penelitian yang digunakan untuk mencari pengaruh perlakuan tertentu terhadap faktor lain dalam kondisi yang terkendalikan (Sugiyono, 2016). Penelitian eksperimen menggunakan suatu percobaan yang dirancang secara khusus guna membangkitkan data yang diperlukan untuk menjawab pertanyaan penelitian (Sugiyono, 2012). Adapun perlakuan yang diberikan adalah memvariasikan lama penyimpanan limbah jamur merang dan volume pupuk organik cair. Sedangakn parameter yang diamati adalah kadar Kalium (K-total) dalam pupuk organik cair yang dihasilkan.

Rancangan penelitian yang digunakan dalam penelitian ini adalah Rancangan Acak Lengkap (RAL) dengan dua faktor perlakuan, yaitu lama penyimpanan limbah jamur merang dan volume pupuk organik cair seperti disajikan pada Tabel 2.

Tabel 2. Rancangan Acak Lengkap

$\begin{array}{cc}\text { Massa Limbah Jamur Merang Baru (b) dan Lama (l) } & \text { Volume POC } \\ 600 \mathrm{gr}(\mathrm{b}) & 1 \mathrm{~L} \\ 600 \mathrm{gr}(\mathrm{l}) & 1 \mathrm{~L}\end{array}$

Alat yang digunakan pada penlitian ini adalah ember, blender, pisau,toples, botol plastik, alat gelas, Neraca analitik,Spektrofotometri Serapan Atom, corong plastik, Erlenmeyer, neraca ohaus, saringan. Bahan yang digunakan pada penelitian ini adalah limbah jamur merang, pupuk organik cair, mikroorganisme lokal (MOL), aquades, $\mathrm{HNO}_{3} 0,5 \mathrm{ml}, \mathrm{HCl}$.

Data penelitian selanjutnya dianalisis menggunakan persamaan [Kadar $\mathrm{K}(\%)=p p m$ kurva $\times$ ml ekstrak/1000 ml x 100/mg contoh x fk] dengan Ppm kurva = kadar contoh yang didapat dari kurva regresi hubungan antara kadar deret standar dengan pembacaannya setelah dikurangi blanko; fk = faktor koreksi kadar air = 100/(100 - \% kadar air $)$; dan100 = faktor konversi ke \% (Eviati \& Sulaeman, 2009).

\section{HASIL PENELITIAN DAN PEMBAHASAN}

Sampel dalam penelitian ini dibagi menjadi 2 sampel, yaitu $600 \mathrm{gr}$ limbah jamur merang baru $+1 \mathrm{~L}$ pupuk organik cair dan $600 \mathrm{gr}$ limbah jamur merang lama $+1 \mathrm{~L}$ pupuk organik cair. Untuk menganalisis kadar kalium diketahui dengan melakukan uji AAS. Sebelum fermentasi dilakukan, analisis kadar kalium (K-total) untuk whey tahu di laboratorium BPTP Narmada. Hasil analisa dapat dilihat pada Tabel 3.

Tabel 3. Hasil analisis kadar K-total

\begin{tabular}{ll}
\hline Sampel & Kadar K-total (\%) \\
\hline Whey tahu & 0,43 \\
\hline
\end{tabular}


Setelah difermentasi selama 16 hari, dilakukan analisis kadar kalium (K-total) di Laboratorium BPTP Narmada. Hasil analisa pupuk organik cair dapat dilihat pada Tabel 4.

Tabel 4. Hasil analisis kadar K-total

\begin{tabular}{lc}
\hline Sampel & Kadar K-total (\%) \\
\hline Pupuk Organik Cair & 0,52 \\
\hline
\end{tabular}

Setelah difermentasi selama 16 hari dan ditambahkan limbah jamur merang lama dan limbah jamur merang baru yang telah dihaluskan,di diamkan semalam dan dilakukan analisa kadar kalium (K-total) di Laboratorium BPTP Narmada. Hasil analisa POC + limbah jamur merang baru dan POC + limbah jamur merang lama dapat dilihat pada Tabel 5.

Tabel 5. Hasil analisis kadar K-total

\begin{tabular}{ll}
\hline Sampel & Kadar K-total (\%) \\
\hline POC + Limbah Jamur Merang Baru & 1,05 \\
POC + Limbah Jamur Merang Lama & 0,71 \\
\hline
\end{tabular}

Dalam penelitian ini dilakukan analisis kadar K total POC dan lama penyimpanan limbah jamur merang. Kadar kalium dalam whey tahu dan limbah jamur merang merupakan jumlah kalium total baik organik ataupun anorganik, karena dalam whey tahu terdapat kadar protein yang tinggi dan pada limbah jamur merang terdapat kadar kalium yang tinggi diakibatkan oleh bahan dasar utamanya yaitu jerami dan sagu. Dari hasil analisis hara tersebut maka whey tahu dan limbah jamur merang dapat digunakan sebagai bahan dasar pembuatan pupuk organik cair (POC). Pupuk organik cair adalah pupuk yang berasal dari hewan atau tumbuhan yang telah difermentasi. Dalam proses fermentasi senyawa organik terurai menjadi senyawa yang lebih sederhana seperti gula, gliserol, asam lemak dan asam amino. Menurut Isroi (2009) mikroorganisme lokal adalah kumpulan mikroorganisme yang bisa "diternakkan", fungsinya dalam konsep zero waste adalah untuk starter yang berfungsi sebagai bioaktivator dalam pembuatan kompos organik.

Tahap selanjutnya adalah whey tahu dan limbah jamur difermentasi menggunakan mikroorganisme lokal selama 16 hari. Berdasarkan penelitian Maulana (2017) menyatakan penggunaan fermentasi limbah tahu menggunakan EM4 dengan konsentrasi yang berbeda berpengaruh terhadap pertumbuhan bakteri. Penambahan limbah jamur merang bertujuan untuk meningkatkan kadar $\mathrm{K}$ pada pupuk cair organik limbah tahu. Penambahan EM4 berfungsi mengaktifkan bakteri pelarut, sehingga mampu mengurangi bahan organik menjadi asam amino yang mudah diserap oleh tanaman dalam waktu cepat (Makiyah, 2011).

Penentuan kadar kalium (K) menggunakan Spektrometri Serapan Atom (SSA). Sebelum dianalisis terlebih dahulu sampel didestruksi dengan tujuan mengoksidasi senyawa organik yang terdapat dalam sampel menggunakan asam kuat $\mathrm{HNO}_{3}$ dan $\mathrm{HCLO}_{4}$. Pada saat destruksi akan timbul asap berwarna kuning kecoklatan kemudian dilanjutkan hingga sampel tersisa $0,5 \mathrm{ml}$ pada labu ukur $50 \mathrm{ml}$. Kemudian setelah didinginkan diencerkan dengan aquades hingga tanda batas agar tidak mengkristal. Lalu didiamkan selama semalam agar mengendap dan tahap selanjutnya ambil $1 \mathrm{ml}$ sampel masukkan kedalam labu ukur $25 \mathrm{ml}$ dan diencerkan dengan aquades sampai tanda batas sehingga didapat larutan yang jernih kemudian diukur dengan menggunakan spektrometri serapan atom (Balai Penelitian Pertanahan Edisi II, 2009).

Penentuan kadar K-total menggunakan spektrometri serapan atom (SSA) didapatkan hasil berupa persen kalium seperti tertera pada Gambar 1. 


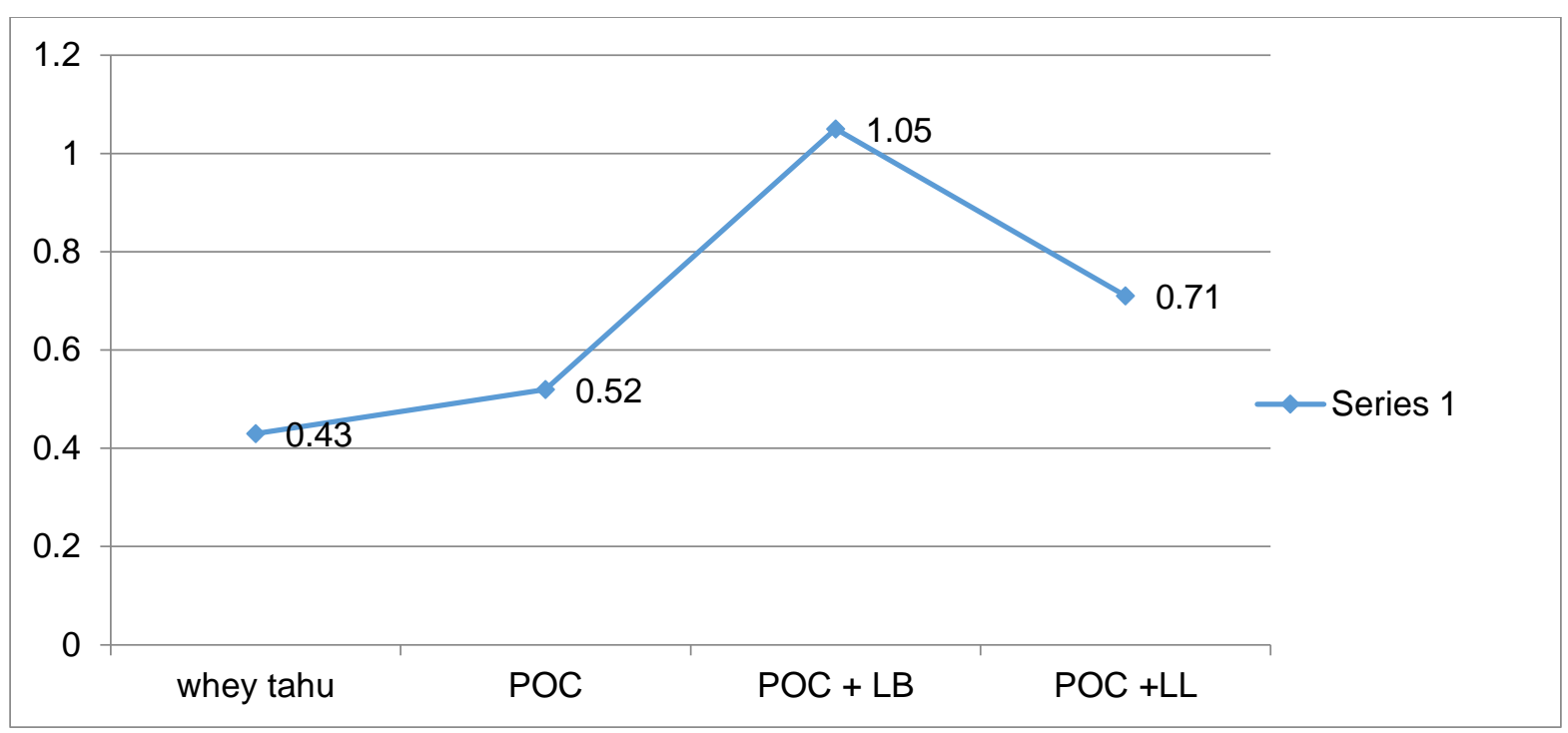

Gambar 1. Kadar K-total

Berdasarkan Gambar 1 di atas, diketahui bahwa pupuk organik cair dengan penambahan limbah jamur merang baru (POC+ LB) memiliki kandungan kalium yang tinggi, yaitu sebesar $1,05 \%$. Hal ini menunjukkan bahwa adanya pengaruh peningkatan kandungan K-total dalam pupuk organik cair setelah penambahan limbah jamur merang baru yang memiliki komposisi utama berupa jerami, limbah sagu dan kapur yang masih cukup utuh dan belum terurai secara keseluruhan sehingga menghasilkan pupuk organik cair dengan kadar kalium yang tinggi. Menurut Dobermen dan Fairhurst (2002) kandungan kalium pada jerami padi sebanyak 1,4-2,0\%. Menurut Syakir (2010), kandungan hara kompos limbah sagu terdiri dari Nitrogen, Posfor, Kalium, Calsium, dan Magnesium, hal tersebut disebabkan selama pengomposan terjadi mineralisasi unsur - unsur hara, sehingga hara makro dan mikro terlepas dan tersedia. Lamanya waktu pengomposan akan meningkatkan hara yang tersedia.

Kalium yang terkandung dalam bahan organik dapat larut dalam air setelah direndam, sehingga akan menghasilkan air rendaman yang mengandung unsur kalium. Kalium merupakan katalistator bagi mikroorganisme untuk mempercepat reaksi fermentasi. Hal tersebut dapat dibuktikan dalam penelitian Hidayati dkk (2010), yang menyatakan bahwa kalium $\left(\mathrm{K}_{2} \mathrm{O}\right)$ digunakan oleh mikroorganisme dalam bahan substrat sebagai katalistator, kehadiran bakteri dengan segala aktivitasnya sangat berpengaruh terhadap peningkatan kandungan kalium. Kalium diikat dan disimpan dalam sel oleh bakteri dan jamur, jika didegradasi kembali maka kalium akan tersedia kembali.

Limbah jamur merang baru yang ditambahkan dalam pembuatan pupuk organik cair bertujuan untuk meningkatkan kadar kalium dalam pupuk, karena dalam limbah jamur merang baru masih terdapat jerami padi utuh yang mengandung unsur - unsur potensial bagi tanaman. Menurut Dobermen dan Fairhurst(2002), 1 ton jerami padi mengandung $\mathrm{N} 0,5-0,8$ $\%, \mathrm{P}_{2} \mathrm{O}_{5}$ 0,16-0,27 \%, $\mathrm{K}_{2} \mathrm{O}$ 1,4-2,0 \%, S 0,050,10\%, dan Si 4-7 \%.Dalam penelitian ini terbukti bahwa dengan penambahan limbah jamur merang baru dapat menghasilkan kandungan kalium yang tinggi dibandingkan dengan penambahan jamur merang lama.

Rendahnya kandungan kalium pada penambahan limbah jamur merang lama disebabkan karena jerami padi yang terdapat pada limbah hampir terurai secara menyeluruh dan telah tercampur dengan tanah dan komponen lainnya.

Berdasarkan hasil penelitian dapat dilihat bahwa adanya pengaruh dari penambahan limbah jamur merang baik yang lama ataupun yang baru yang bisa dilihat pada gambar 4.4 penentuan $\mathrm{k}$ - total pupuk organik limbah tahu. Hal ini disebabkan oleh perbedaan kecepatan mikroorganisme dalam mengurai bahan organik saat fermentasi Mulyadi (2013).Selain itu juga dapat disebabkan oleh perbedaan kandungan jerami padi antara limbah jamur merang baru dan limbah jamur merang lama. Kalium dalam pupuk cair ini tergolong rendah dan belum memenuhi standar mutu. Menurut Mentri Pertanian No 70 Tahun 2011, standar mutu kalim 
yaitu $3-6 \%$. Sedangkan pupuk organik cair yang dihasilkan dalam penelitian ini mengandung kalium $<2 \%$.

\section{KESIMPULAN}

Berdasarkan hasil penelitian yang diperoleh dapat disimpulkan bahwa adanya pengaruh terhadap K - Total dalam pupuk organik cair setelah penambahan limbah jamur merang baik limbah lama ataupun limbah baru. Pupuk organik cair yang memiliki kadar kalium (K-Total) yang tinggi adalah pupuk organik cair dengan penambahan $600 \mathrm{gr}$ limbah jamur merang baru kedalam 1 liter pupuk organik cair yang menghasilkan kadar K-total sebesar 1,05\%, sementara itu kandungan K-total dalam 1 liter pupuk organik cair dengan penambahan 600 gr limbah jamur merang lama menghasilkan kadar K-total sebanyak 0,71\%.

\section{SARAN}

Dari hasil penelitian yang dilakukan kadar kalium optimum yang diperoleh masih belum memenuhi Standar Nasional Indonesia (SNI). Kadar kalium tertinggi sebesar 1,05\% dari pencampuran 600 gram limbah jamur merang baru dengan 1 L POC. Jika ingin melakukan penelitian selanjutnya, maka perlu adanya variasi dari setiap massa limbah jamur merang baik limbah lama ataupun limbah baru, variasi volume pupuk organik cair dan lama fermentasi yang dilakukan agar kadar kalium optimum yang sesuai SNI dapat dihasilkan.

\section{UCAPAN TERIMAKASIH}

Penelitian ini tidak menerima hibah khusus dari agensi pendanaan mana pun di sektor publik, komersial, atau nirlaba.

\section{DAFTAR PUSTAKA}

Aliyenah, A Napoleon Yudono. 2015. Pemanfaatan Limbah Cair Industri Tahu Sebagai Pupuk Cair Organik Terhadap Pertumbuhan danProduksi Tanaman Kangkung Darat (Ipomoea reptans poir). Jurnal Penelitian Sains. Volume 17 Nomor 3 September 2015. Diakses tanggal 1 oktober 2017 di https//media neliti.com/media/publications/16849-IDpemanfaatan-Limbah-Cair-Industri-Tahu-Se. Pdf.

Darmono dan Tri Panji. 1999. Penyediaan Kompos Kulit Buah Kakao Bebas Phytophthora Palmivora. Warta Penelitian Perkebunan. V (1):33-38

Desiana, Christina; Irwan Banuwa; Rusdi Evizal; dan Yusnaini.2013. Pengaruh Pupuk Organik Cair dan Limbah Tahu terhadap Pertumbuhan Bibit Kakao ( Theobroma cacao, L.). Jurnal Agrotek. 1. (1): 113-119. ISSN 2337-4993.

Eviati dan Sulaeman. 2009. Petunjuk Teknis Analisis Kimia Tanah, Air, dan Pupuk Edisi ke-2. Balai Penelitian Tanah. Bogor .

Gunawan. A. W. 2000. Usaha Pembibitan Jamur. Penebar Swadya. 112 hal.ISBN 979-489539-3.

Hadisuwito, S. 007. Membuat Pupuk Kompos Cair,PT. Agromedia Pustak:Jakarta.

Hartini, 2012. Pemanfaatan Batang Jagung (Zeamays L.) Sebagai Campuran Media Tanam Pada Budidaya Jamur Merang (Volvariella Volracea). Undergraduate Tesis. Yogyakarta: UKDW

Hersanti 2007.Isolasi Bakteri Asal Larutan Mikroorganisme Lokal, Uji Antagonis, Uji Pertumbuhan Semai Padi. Faperta UNPAD. Jatinangor.87 hal.

Islamiyati, R. 2009. Kandungan Nutrisi Campuran Ampas Sagu(Metroxilon Sago) dan Feses Broiler yang Difermentasikan dengan Berbagai Level EM4. Seminar Nasional Teknologi Peternakan dan Veteriner.

Isroi.2007. Pengomposan Limbah Kakao.Balai Penelitian Bioteknologi Perkebunan Indonesia, Bogor. Dikutip dari http://www.Isroi.org.Diakses tanggal1 April 2015

Isroi. 2009. Pupuk Organik Granul: Sebuah Petunjuk Praktis. C.V Andi Offset:Yogyakarta.50 hal.

Kaswinarni, F. 2007. Kajian Teknis Pengelolaan Limbah Padat dan Cair Industri Tahu Studi Kasus Industri Tahu Tandang Semarang, Sederhana Kendal dan Gaagak Sipat Boyolali. Tesis.Program Pasca Sarjana Undip. Semarang. 
Kurnia ,K. P, Arbianto, dan I. N. P. Aryantha.2003. Studi Patogenitas Bakteri Entamopathogenik Lokal Pada Larva Hyposidrafalaka wlk dan Optimasi Medium Pertumbuhan nya.Seminar Bulanan Bioteknologi-PPAU Bioteknologi ITB. 15 September 2004. Bandung.

Makiyah, Mujiatul. 2013. Analisis Kadar N, P dan K Pada Pupuk Cair Limbah Tahu Dengan Penambahan Tanaman Matahari Meksiko (Thitonia Diversivolia).Skripsi.KIMIA: Universitas Jember.

Malezieu E and Bartholomew DD. 2003. Plant Nutrition.didalam: Bartholomew DP, Paul RE and Rohbach KG,Edited. The Pineapple Botany,Production and Uses. USA. New York. CABI Polising. HIm. 143-166.

Maulana Panji Muhammad, Sofyatuddin Karina, \& Siska Mellisa.2017. Pemanfaatan Fermentasi Limbah Cair Tahu menggunakan EM4 sebagai Alternatif Nutrisi bagi Mikroalga Spirulina Sp. Jurnal IImiah Kelautan dan Perikanan Unsyiah.2 (1): 104-112. ISSN: 2527-6395.

Mohsin , Yulianto.2006. Kalium.www.chem-is-try.org/tabelperiodik/kalium/

Muhamad Aip Irpan.2011.Respon Tanaman Kedelai dan Padi Gogo Terhadap Limbah budi Daya Jamur Tiram.Skripsi.Bogor :Institut Pertanian Bogor.

Nohong. 2010. Pemanfaatan Limbah Tahu Sebagai Bahan Penyerap Logam Krom, Kadium dan Besi dalam Air Lindi TPA. Kendari: Jurusan Kimia FPMIPA Universitas Haluoleo Kendari. 6(2): 257-269

Pohan, N. 2008.Pengolahan Limbah Cair Tahu dengan Proses Biofilter Aerobik. Tesis.Medan: Sekolah Pascasarjana Universitas Sumatera Utara.

Purwasasmita M, Kurnia K.2009. Mikroorganisme Lokal Sebagai Pemicu Siklus Kehidupan Dalam Bioreaktor Tanaman. Seminar Nasional Teknik Kimia Indonesia-SNTKI 2009.Bandung 19-20 oktober 2009.

Samekto, R. 2008. Pemupukan .Pt. Citra Aji Prama.Yogyakarta .44 hal.

Sugiyono .2012. Metode Penelitian Kuantitatif Kualitatif dan R\&D. Bandung Alfa Beta.

Sugiyono . 2016. Statistika untuk Penelitian. Bandung: Alfabeta.

Sutanto ,, R.2002. Pertanian Organik : Menuju Pertanian Alternatif dan Berkelanjutan. Yogyakarta : Kanisius.

Sutedjo, M.M. 2010. Pupuk dan Cara Pemupukan.Rineka Cipta. Jakarta.

Warta Kusuma.2010. Studi Kandungan Nutrisi Limbah MediaTanam Jamur Tiram Putih untuk Pakan Ternak. (http://www.ut.ac.id/htm/jmst/Jurnal2010(Diakses pada tanggal 07 November 2014)

Winarso, S. 2005. Kesuburan Tanah: Dasar Kesehatan dan Kualitas Tanah. Gara Media. Jogjakarta .269 hal.

Yulipriyanto, H. 2010. Biologi Tanah dan Strategi Pengelolaannya.Graha Ilmu. Yogyakarta. 